\title{
Comparison of the microbiological and hygienic quality of turkey meat between six districts of the Kenitra city
}

\author{
Hassna Jaber ${ }^{1}$, Rachid Ijoub ${ }^{1}$, Rahma Erahioui ${ }^{1}$, Rachid Boulamtat ${ }^{2}$, Ali Oubayoucef ${ }^{3}$, Brahim Bourkhiss ${ }^{1}$, and \\ Mohammed Ouhssine ${ }^{1}$ \\ ${ }^{1}$ Laboratory of Natural Resources and Sustainable Development, Department of Biology, Faculty of Sciences, Ibn Tofail University, \\ Kenitra, Morocco \\ ${ }^{2}$ Laboratory of Biology and Health, Department of Biology, Faculty of Sciences Ibn Tofail University, Kenitra, Morocco \\ ${ }^{3}$ Laboratory of Biochemistry and Immunology, Department of Biology, Faculty of Sciences Mohamed V University, Rabat, Morocco
}

\begin{abstract}
Meat is known to be one of the vehicles for many diseases to humans. The aim of this study is the comparison of the microbiological and hygienic quality of fresh turkey meat marketed in the most popular districts of Kenitra city. Fresh meat samples were taken from stores localized in six different districts. Microorganisms tests were conducted according to the appropriate standards. The Aerobic Mesophilic Flora (AFM) was most counted in district five $\left(7.69 \pm 0.212 \log _{10} \mathrm{ufc} / \mathrm{g}\right)$, while the highest total and fecal coliform charges were obtained in district six with rates of $7.68 \pm 0.160$ and $6.89 \pm 0.132 \log _{10 u f c} / g$, respectively. Cases of Salmonella spp were observed in all districts, except district five with frequencies up to $10.71 \%$. Pseudomonas aeuroginosa charge was high in district five and its prevalence was high $(21.42 \%)$ in districts two, four and six. Regarding Clostridium perfringens, the charges were up to $2.11 \pm 0.55 \log _{10} \mathrm{ufc} / \mathrm{g}$ in district six and a high prevalence of $42.85 \%$ was in district four. Escherichia coli showed dominance in all the districts studied with a high prevalence in district four with a rate of $75 \%$ and a high charge in district five (4.37 $\log _{10} \mathrm{ufc} / \mathrm{g}$ ). The presence of Staphylococcus aureus was significant in district four with a rate of $28.57 \%$ and a high concentration in district five $\left(4.47 \log _{10} \mathrm{ufc} / \mathrm{g}\right)$. This study has shown great variability in the results found between the different districts and the rate of contaminations affecting this product. In fact, this microbiological and hygienic quality of raw turkey meat sold in these districts was judged marginal indicating the need for improved hygienic standards.
\end{abstract}

Key words: turkey meat, prevalence, bacterial charge, districts, contamination

\section{Introduction}

The poultry sector constitutes one of the most dynamic agricultural activities in Morocco, with an average growth rate over the last four decades around $7.7 \%$ of poultry meat production. Thus, the current production satisfies all the national needs and covers $100 \%$ of the poultry meat needs, representing $52 \%$ of the total consumption of meat. Poultry products (meat and eggs) contribute $38 \%$ of the protein intake of animal origin [1]. In fact, in 2019 the consumption of turkey meat in Morocco reached 22.1 $\mathrm{Kg} / \mathrm{inhab} / \mathrm{yr}$, of which the sector supplied an average of 964384 tonnes of turkey meat [2]. This meat has just taken an important place in the Moroccan diet because of its relatively low prices compared to other animal foodstuffs, poultry products are consumed by the whole population and constitute the only recourse for the improvement of food security in the country in terms of proteins of animal origin [1]. However, the problems of the poultry sector in terms of health remain dependent on the conditions of rearing in general, and more particularly on the hygiene of buildings [3]. This not only affects the productivity of poultry workshops, but also presents a threat to the public health [3]. Thus, food safety has become a major issue to the public authorities, consumers and professionals of the related products intended for human consumption. Meat's high amount of proteins makes it very suitable for microbial proliferation and thus, a large proportion of germs contaminate the carcasses following the various stages of slaughter. The presence of these pathogenic germs is responsible for the food-borne diseases. According to an investigation into outbreaks of collective foodborne disease (CBD) in Kenitra Provincial Hospital during the period (2007 - 2009), they revealed 14 cases of CBD in the Gharb-Chrarda-Bnihsein region, with the largest number of outbreaks reported in Kenitra city with a percentage of $50 \%$, including poultry meat which is among the foodstuffs responsible for CBD with a rate of $14 \%$ [4]. During slaughter and processing, all potentially edible tissues are subjected to contamination from a variety of sources within and outside the animal [5]. The pathogenic microorganisms that are implicated in contaminating meat and its products include; Salmonella spp., Shigella spp., Campylobacter jejuni, Campylobacter coli, Yersinia enterocolitica, verotoxigenic Escherichia coli and Listeria monocytogenes [6]. Staphylococcus aureus contaminates meat through unhygienic handling of the meat and its products by butchery staff as this organism is a normal flora of the human skin [7]. Contamination of meat with this microorganism is an indication of poor evisceration [6] and poor hand hygiene among the handlers [8]. Meat and their products when contaminated can serve as vehicles of pathogens to consumers and also reduces the shelf life of the product.

In order to intensify and deepen the results of the preliminary study [9], our objective is the comparison of the microbiological quality of turkey meat marketed at the most popular districts in Kenitra city (Morocco).

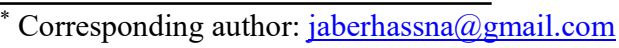




\section{Material \& Methods}

\subsection{Sampling}

The samples were taken from stores in six of the most popular districts in Kenitra city, which differ in their socioeconomic levels. 180 samples were collected as 30 samples per district during the period of June-September 2018.

Table 1. Setting Word's margins.

\begin{tabular}{|c|c|c|}
\hline Study area & $\begin{array}{c}\text { Number of } \\
\text { districts }\end{array}$ & $\begin{array}{c}\text { Number of } \\
\text { sample/districts }\end{array}$ \\
\hline \multirow{4}{*}{ Kenitra } & 1 & 30 \\
\cline { 2 - 3 } & 2 & 30 \\
\cline { 2 - 3 } & 3 & 30 \\
\cline { 2 - 3 } & 4 & 30 \\
\cline { 2 - 3 } & 5 & 30 \\
\hline Total & 6 & 30 \\
\hline
\end{tabular}

Each sample was placed in a sterile plastic food bag and transported to the laboratory in an insulated icebox that has been properly cleaned and has a temperature not exceeding $+4^{\circ} \mathrm{C} \pm 1^{\circ} \mathrm{C}$. At arrival, the samples were immediately analyzed in three replicates.

\subsection{Microbiological analyses}

The search for microorganisms in the different samples requires several steps. Starting with weighing, dilution, isolation, enumeration and identification. $25 \mathrm{~g}$ of each sample was taken from each jar and mixed with $225 \mathrm{ml}$ of buffered peptone water (Oxoid, England) to make the stock suspensions.

\subsubsection{Enumeration of the total mesophilic aerobic flora (TMAF)}

Enumeration of TMAF was performed by diluting the sample in broth buffered peptone water, plating on Plate Count Agar (PCA) (Oxoid, England) and incubating at $30^{\circ} \mathrm{C}$ for 72 hours [10] (NM 08.0.184, 2012). Petri dishes with a colony count ranged between 30 and $300 \mathrm{CFU}$ were counted.

\subsubsection{Enumeration of Fecal and Total Coliforms}

Fecal and total coliform counts were made on the Violet Red Bile Lactose Agar (VRBL) (Oxoid, England). The Petri dishes were incubated at $37^{\circ} \mathrm{C}$ for 24 hours and at $44^{\circ} \mathrm{C}$ for 24 hours for total coliforms and fecal coliforms, respectively.

\subsubsection{Detection and enumeration of Escherichia Coli}

Colonies of fecal coliforms were isolated from the VRBL medium (Oxoid, England) and transplanted into another selective medium Eosine Methylene Blue (EMB) (Oxoid, England). After incubation of the Petri dishes at $37^{\circ} \mathrm{C}$ for 24 hours. The presence of E. Coli was indicated by the metallic sheen and the green color of the colonies [11] (NM 08.0.127, 2012).

\subsubsection{Detection and enumeration of Staphylococcus aureus}

The count was carried out on Baird Parker agar agar (Oxoid, England) with added egg yolk and tellurite. After incubation at $37^{\circ} \mathrm{C}$ for 24 hours, colonies of Staphylococcus aureus appear glossy black, domed and surrounded by an opaque white border and a brightening halo. Their presence is confirmed by catalase and coagulase tests.

\subsubsection{Detection for Salmonella. spp}

Salmonella. spp testing of food is performed by taking 25 grams of homogenized food in $225 \mathrm{ml}$ of buffered peptone water (Oxoid, England) pre-enrichment diluent. After incubation for 24 hours at $37^{\circ} \mathrm{C}, 1 \mathrm{ml}$ of the resulting culture is inoculated into a sterile test tube containing 9 $\mathrm{ml}$ of Rappaport-Vassiliadis selective (Oxoid, England) enrichment broth and incubated for 24 hours at $43^{\circ} \mathrm{C}$. The initial color change of the broth indicates a positive reaction. Isolation is carried out on the selective medium: Hektoen agar (Oxoid, England), the plates were incubated for 24 hours at $37^{\circ} \mathrm{C}$. The characteristic Salmonella spp colonies are smooth and green in color with black centers.

\subsubsection{Detection and enumeration of Pseudomonas aeuroginosa}

Pseudomonas colonies were cultured on Pseudomonas Agar medium (Oxoid, England) after incubation of the plates at $44^{\circ} \mathrm{C}$ for 48 hours. The colonies were colored or green with a light halo.

\subsubsection{Detection and enumeration of Clostridium perfringens}

The Clostridium enumeration was carried out on the TSC (Tryptone-Sulfite-Cycloserine) medium (Oxoid, England). The inoculated Petri dishes were incubated at $46^{\circ} \mathrm{C}$ for 24 to 48 hours. The reading was taken quickly after opening the Petri dishes, otherwise the colonies may turn pale due to iron sulphide oxidation. The colonies are surrounded by a black halo.

The microbial colonies formed were calculated based on the Standard Plate Count (SPC) with the following formula: 


\section{Total Population $=\frac{\mathbf{N}}{(\mathbf{n} \mathbf{1}+(\mathbf{0 . 1} \times \mathbf{n} 2)) \times \mathbf{d}}$}

$\mathrm{N}=$ Number of different colonies in the count range (30-300 colonies). $\mathrm{n} 1=$ The number of the first cup whose colonies can be counted. $\mathrm{n} 2=$ Number of second cups whose colonies can be counted. $\mathrm{d}=$ The first dilution calculated

\subsection{Biochemical confirmation and identification}

All bacteria were tested for Gram stain and oxidase activity was done for Escherichia coli, Pseudomonas aeuroginosa, Clostridium perfringens, Salmonella spp, as well as a coagulase test for Staphylococcus aureus. In addition, the identification of isolates is carried out by biochemical profiling using the API gallery (Bio Mérieux, Marcy l'Etoile, France).

\subsection{Statistical Analysis.}

Data were expressed as mean values \pm standard deviation for each measurement. The statistical study is performed using GraphPad Prism 8 software. A probability of $\mathrm{P}<0.05$ indicates that the values are considered statistically significant.

\section{Results \& Discussion}

The results of the enumeration of TMAF, total and fecal coliforms in the meat of the poultry from the different districts studied are presented in Table 2.

Table 2: Enumeration of TMAFs, total coliforms and fecal coliforms in samples from the six districts

\begin{tabular}{cccc}
\hline Districts & $\begin{array}{c}\text { TMAF } \\
\log _{10} \mathrm{ufc} / \mathrm{g}\end{array}$ & $\begin{array}{c}\mathrm{CT} \\
\log _{10} \mathrm{ufc} / \mathrm{g}\end{array}$ & $\begin{array}{c}\mathrm{CF} \\
\log _{10} \mathrm{ufc} / \mathrm{g}\end{array}$ \\
\hline $\mathbf{Q 1}$ & $6.44 \pm 0.267$ & $6.47 \pm 0.208$ & $5.87 \pm 0.237$ \\
\hline $\mathbf{Q 2}$ & $6.54 \pm 0.144$ & $6.01 \pm 0.318$ & $5.75 \pm 0.301$ \\
\hline $\mathbf{Q 3}$ & $7.32 \pm 0.176$ & $6.46 \pm 0.351$ & $5.38 \pm 0.225$ \\
\hline $\mathbf{Q 4}$ & $6.77 \pm 0.033$ & $5.97 \pm 0.792$ & $5.12 \pm 0.965$ \\
\hline $\mathbf{Q 5}$ & $7.69 \pm 0.212$ & $7.04 \pm 0.450$ & $6.14 \pm 0.451$ \\
\hline Q6 & $7.18 \pm 0.070$ & $7.68 \pm 0.160$ & $6.89 \pm 0.132$ \\
\hline Standard* & $\mathbf{6 , 7}$ & - & $\mathbf{4}$ \\
\hline $\begin{array}{l}\text { Q: } \text { Districts; C.T : Total Coliforms; C.F : Fecal Coliforms; TMAF : Total Aerobic Mesophilic } \\
\text { Flora. } \\
\text { Standard*: Moroccan microbiological standard that must be met by animal foodstuffs or } \\
\text { foodstuffs of animal origin. }\end{array}$ & & &
\end{tabular}

Q5 and Q1 have shown the highest and lowest TMAFs values as $7.69 \log _{10} \mathrm{ufc} / \mathrm{g}$ and $6.44 \log _{10} \mathrm{ufc} / \mathrm{g}$, respectively. Similar results were found by Amara et al [12], Cohen et al [13], and Chaiba and Filali [14], which their values were around 7. $15 \log _{10} \mathrm{ufc} / \mathrm{g}, 7.4 \log _{10} \mathrm{ufc} / \mathrm{g}$. and 7.45 $\log _{10} \mathrm{ufc} / \mathrm{g}$, respectively. However, lower scores were reported by Chu Thi Thanh Huong et al [15] and Abdellah et al, [16] with a rate of $5.07 \log _{10} \mathrm{ufc} / \mathrm{g}$ and 5.69 $\log _{10} \mathrm{ufc} / \mathrm{g}$, respectively.

Regarding the total coliforms, the highest value was found in Q6 samples $7.68 \log _{10} \mathrm{ufc} / \mathrm{g}$ followed by $7.04 \log _{10} \mathrm{ufc} / \mathrm{g}$ in Q5 samples. The minimum average value was found in Q2 samples $6.01 \log _{10} \mathrm{ufc} / \mathrm{g}$. These values are higher than those found in chicken carcasses from the traditional slaughterhouses in the city of Meknes by Chaiba et al, [14], where the abundance of total coliforms recorded was around $4.4 \log _{10 \mathrm{ufc}} / \mathrm{g}$.

While for fecal coliforms, the highest average value was recorded in Q6 samples as $6.89 \log _{10} \mathrm{ufc} / \mathrm{g}$. The lowest average value was found in Q4 samples $5.12 \log _{10} \mathrm{ufc} / \mathrm{g}$. These values are higher than the $3.9 \log _{10} \mathrm{ufc} / \mathrm{g}$ and 1.25 $\log _{10}$ ufc/g found by Cohen et al [13] and Chu Thi Thanh Huong et al [15], respectively.

Figure 1 illustrates the comparison of our TMAFs results with the Moroccan microbiological standard to which animal foodstuffs or foodstuffs of animal origin, which shows that a variation in non-compliance from one station to another. The non-compliance rates were $53.57 \%$, $64.29 \%$ and $78.57 \%$ in the stations Q1, Q2 and Q4, respectively, which are higher than the rate $(48.95 \%)$ reported by Abdellah et al [16]. The Q3, Q5 and Q6 record an average non-compliance rate. Thi Thanh Huong et al [15], reported a higher rate which was around $69.77 \%$.

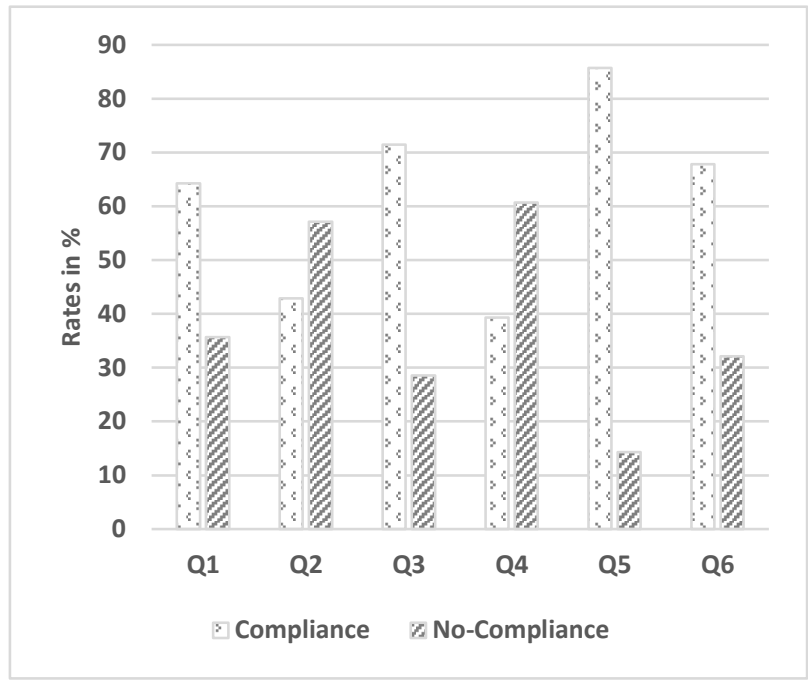

Figure 1: Compliance and non-compliance rates of samples from different districts for Total Mesophilic Aerobic Flora (TMAF).

Figure 2 represents the compliance rates of fecal coliforms with the Moroccan standards. It shows that Q4 and Q2 were higher than the norms as their values reached $60.71 \%$ and $57.14 \%$, respectively. The rest of the stations showed moderate rates, however, our results were higher than the rate [13] Cohen et al (2007) which was 22.4\% except for Q5. Thi Thanh Huong et al [15] reported a higher rate up to $72.09 \%$. 


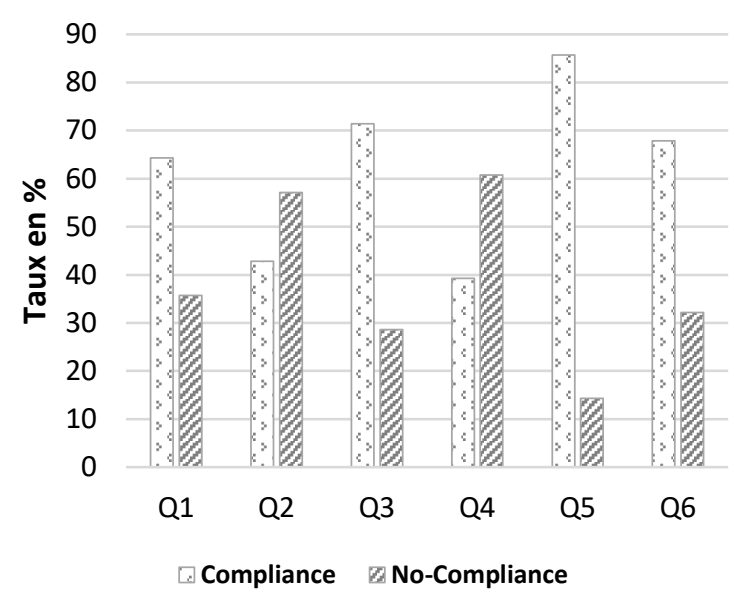

Figure 2: Compliance and non-compliance rates for fecal coliforms in samples from different districts

These non-compliance rates for TMAF and fecal coliforms could be explained by contamination of the viscera's germs during evisceration. Although the majority of these germs are not pathogenic, they can be responsible for foodborne illness in humans.

Results showed dominance of $E$. coli prevalence in Q4 with a rate of $75 \%$ with bacterial charge $2.15 \log _{10} \mathrm{ufc} / \mathrm{g}$. Q2 also had high E. coli prevalence with a rate of $71.4 \%$ and a bacterial charge of $2.08 \log _{10} \mathrm{ufc} / \mathrm{g}$. the rest of the districts had moderate prevalence but with high bacterial charges (Table. 3). However, our results were lower than those of El Allaoui et al [3] with a rate of $83 \%$ and higher than those reported by Zhao et al [17], Gupta and Gupta [18] and Iroha et al [19], which were $11.60 \%, 22.5 \%$ and $2 \%$, respectively. The $E$. coli prevalence found in our study indicates a lack of good hygiene practices among the staff responsible for sales and in their premises [20], it could be also being due to a defect in the slaughter process [21].

Pseudomonas aeuroginosa showed dominance in Q2, Q4 and Q6 with the same prevalence of $21.42 \%$ with bacterial charges of $3.27 \log _{10} \mathrm{ufc} / \mathrm{g}, 2.83 \log _{10} \mathrm{ufc} / \mathrm{g}$ and 4.96 $\log _{10} \mathrm{ufc} / \mathrm{g}$, respectively. Our results are inferior to those reported by Boudouika and Ghiat [22], with a predominance up high to $61.53 \%$ (Table. 3). Regarding the bacterial charges, our results varied between 2 and 5 $\log _{10} \mathrm{ufc} / \mathrm{g}$, which is similar to the finding of Hutchison et al [23]. The average bacterial charges should be around $4.5 \log _{10} \mathrm{ufc} / \mathrm{g}$ according to Ghafir et al [24].
The presence of Pseudomonas aeuroginosa in food, mainly in meat, reflects poor preservation over time [27; 26], and with high concentrations could lead to the alteration of the contaminated product by degrading the protein chains. A bad smell and yellow-green pigmentation are common indicators to advanced contamination by $P$. aeuroginosa $[26 ; 27]$.

Clostridium perfringens was found dominant in Q4 with a prevalence of $42.85 \%$ and $1.41 \log _{10} \mathrm{ufc} / \mathrm{g}$ bacterial charge, followed by Q3 with a prevalence of $32.14 \%$ and $1.84 \log _{10}$ ufc/g bacterial charge. Q5 and Q6 had both a prevalence of $10.71 \%$ and bacterial charge of 1.71 $\log _{10} \mathrm{ufc} / \mathrm{g}$ and $2.11 \log _{10} \mathrm{ufc} / \mathrm{g}$ respectively (Table. 3 ). Our results are lower than those found by Van Immerseel et al [28] in poultry meat which detected a prevalence of $84 \%$. Results from Q2, Q3 and Q4 were higher than those found by Lindblad et al [29], with a rate of $18 \%$. However, Q1, Q5 and Q6 showed lower rates compared to the results reported by Cohen et al [13] and Wen and McClane [30], with rates of $1.6 \%$ and $2 \%$, respectively. Even though Clostridium perfringens have relatively lower rates than E. coli and Pseudomonas aeuroginosa, it causes severe intoxication with various symptoms and even could lead to fatal outcomes.

The dominance of Staphylococcus aureus was found in Q4 with a rate of $28.57 \%$ and a bacterial charge of 2.80 $\log _{10} \mathrm{ufc} / \mathrm{g}$, followed by Q3 with a rate of $25 \%$ and bacterial charge of $3.11 \log _{10} \mathrm{ufc} / \mathrm{g}$ (Table. 3). with the exception of Q2, all our results are higher than the $10.4 \%$ reported by Cohen et al [13]. However, only the bacterial charge of Q5 was higher than the acceptable limit of the microbial flora in poultry meat set by the Moroccan standards (3.7 $\left.\log _{10} \mathrm{ufc} / \mathrm{g}\right)$. In Spain, $S$. aureus was detected in $60 \%$ of wings and giblets and in $40 \%$ of chicken legs [31]. The source of contamination could be the animal itself as well as the environment [32;33], and its presence in food products represents a risk to public health because of its ability to cause food poisoning or foodborne illness [34].

Salmonella spp was dominant in Q3 and Q4 with a prevalence of $10.71 \%$, low rates were found in Q2, Q1 and Q6 while the bacteria were absent in Q5 (Table. 3). These results were higher than those found by Cohen et al [13] and Zhao et al [17] with rates of $1.56 \%$ and $2.6 \%$ respectively. However, other studies have reported higher rates either on chicken or turkey meat $[15 ; 35 ; 36]$. Salmonella is a serious threat to human health and considered a major cause of foodborne illness in humans. It indicates fecal contamination and it can persist on

Table 3 Prevalence of E. Coli, P. aeuroginosa, C. perfringens, S. aureus and Salmonella spp. In the six different districts with their bacterial charges.

\begin{tabular}{|c|c|c|c|c|c|c|c|c|c|c|}
\hline & \multicolumn{2}{|c|}{ Escherichia Coli } & \multicolumn{2}{|c|}{ P. aeuroginosa } & \multicolumn{2}{|c|}{ C. perfringens } & \multicolumn{2}{|c|}{ S. aureus } & \multicolumn{2}{|c|}{ Salmonella $S p$} \\
\hline & $\mathrm{P}$ & B C & $\mathrm{P}$ & B C & $\mathrm{P}$ & B C & $\mathrm{P}$ & B C & $\mathrm{P}$ & \\
\hline Q1 & 60,7 & $2,27 \pm 0,186$ & 17,85 & $3,016 \pm 0,32$ & 14,28 & $2,09 \pm 0,28$ & 17,85 & $2,363 \pm 0,32$ & 3,57 & - \\
\hline Q2 & 71,4 & $2,08 \pm 0,27$ & 21,42 & $3,276 \pm 0,05$ & 25 & $2,50 \pm 0,28$ & 7,14 & $1,923 \pm 0,05$ & 7,14 & - \\
\hline Q3 & 64,28 & $3,69 \pm 0,06$ & 14,28 & $5,43 \pm 0,35$ & 32,14 & $1,87 \pm 0,26$ & 25 & $3,117 \pm 0,35$ & 10,71 & - \\
\hline Q4 & 75 & $2,15 \pm 0,28$ & 21,42 & $2,83 \pm 0,34$ & 42,85 & $1,41 \pm 0,40$ & 28,57 & $2,807 \pm 0,34$ & 10,71 & - \\
\hline Q5 & 46,42 & $4,37 \pm 0,14$ & 7,14 & $6,68 \pm 0,15$ & 10,71 & $1,71 \pm 0,53$ & 10,71 & $4,477 \pm 0,15$ & 0 & - \\
\hline Q6 & 52,4 & $3,36 \pm 0,31$ & 21,42 & $4,96 \pm 0,19$ & 10,71 & $2,11 \pm 0,55$ & 14,28 & $2,840 \pm 0,19$ & 3,57 & - \\
\hline
\end{tabular}

P (\%): Prevalence; BC: Bacterial Charge $\left(\log _{10 u f c} / \mathrm{G}\right)$; Q: District 
equipment after hygiene operations and could contaminate other batches and poultry $[37 ; 38]$.

\section{Conclusion}

The present study was carried out on six different districts of Kenitra city and it revealed that the district Q3 and Q4 showed higher prevalence of almost all the studied bacteria and thus the most contaminated sites. The studied districts showed signs of contamination with bacterial charges higher than the tolerated limit of the Moroccan standards besides. Regarding Salmonella spp, only the Q5 district showed no contamination. Our results suggest the need of the increase of hygiene protocols and practices. Further studies targeting different steps from slaughter to local stores on the same chain lines most preferably those corresponding to Q3 and Q4 to investigate at which point the contaminations occur and thus suggest the proper precautions to increase the quality of the turkey meat and minimize any threat to the consumers.

\section{References}

[1] Agriculture du Maghreb, Revue professionnelle des filières fruits et légumes, céréalière, élevage, $\mathrm{N}^{\circ} 89$ Novembre 2015 p 12. (2015).

[2] FISA, Présentation du secteur avicole. Visiter le $\begin{array}{lllll}\text { Mercredi } & 19 & \text { mai } & 2020 .\end{array}$ http://www.fisamaroc.org.ma/

[3] A. El Allaoui, F. Rhazi Filali, N. Ameur, Bouchrif B. Contamination des élevages de dinde de chair par Salmonella spp. au Maroc : prévalence, antibiorésistances et facteurs de risque associés. Rev. Sci. Tech. Off. Int. Epiz., 2017, 36 (3), 935-946. (2017)

[4] M. Belomaria, Y. Aboussaleh, A.O.T. Ahami, O. Bouazza, M. Mahly, Y. Khayati. Evolution des toxiinfections alimentaires collectives dans la région du Gharb-Chrarda-BniHsein au Nord Ouest du Maroc. Antropo, 21, 79-84. (2010) www.didac.ehu.es/antropo

[5] A. S. M. Abuelnaga, K. A. E. H. Abd El-Razik, N. S. Ata, R. H. Hedia, E. A. E. Elgabry, M. M. H. Soliman, H. S. A. W. Marie. Bacteriological assessment and multiplex-PCR test for the detection of meat adulteration of different animal species. Food Science and Technology, (AHEAD). (2020).

[6] S. Hanyinza, K. Ndashe, R. L. Mfune, E. Chirwa, G. Mwanza, B. Phiri, B. Mumba, M. Mubanga, \&, B. M. Hang'ombe. Bacteriological Quality of Beef and Hygiene Practices of Food Handlers in Butcheries in Kasama District, Zambia. medRxiv. (2020) https://doi.org/10.1101/2020.06.06.20124214;

[7] D. G. Ngai, A. K. Nyamache, O. Ombori. Prevalence and Antimicrobial Resistance Profiles of Salmonella Species and Escherichia coli Isolates from Poultry Feeds in Ruiru Sub-County, Kenya. (2020).
[8], A.M. Ahmed, T. Shimamoto. Isolation and molecular characterization ofSalmonella enterica, Escherichia coli O157: H7 and Shigella spp. from meat anddairy products in Egypt. Int. J. Food Microbiol. 168, 57-62. (2014).

[9] H. Jaber, R. Ijoub, A. Zaher, M. Chakit, N. Rhaiem, B. Bourkhiss, M. Ouhssine. Microbiological Study of Turkey Meat Marketed in Kenitra (North-oust of Morocco). J Nutr Food Sci.2017, 7: 620. doi: 10.4172/2155-9600.1000620. (2017).

[10] NM 08.0.184, Dénombrement des micro-organismes par comptage des colonies obtenues à $30^{\circ} \mathrm{C}$ après ensemencement par la méthode spirale (2012).

[11] NM 08.0.127. Méthode horizontale pour la recherche et le dénombrement d'Escherichia coli présumés Technique du nombre le plus probable (2012).

[12] A. Amara, M. Badoum, M. Faid, K. Bouzoubaa. Microbial contamination of poultry slaughtered in traditionl shops in Morocco Microbial Aliments Nutrition.12:323-327. (1994).

[13] N. Cohen, H. Ennaji, B. Bouchrif, M. Hassar . H. Karib. Comparative Study of Microbiological Quality of Raw Poultry Meat at Various Seasons and for Different Slaughtering Processes in Casablanca (Morocco) J Appl Poult Res (2007) 16 (4): 502-508. (2007).

[14] A. Chaiba, F. Rhazi Filali. Impact des opérations d'abattage dans les tueries traditionnelles sur la qualité bactériologique de la viande de volaille à Meknès (Maroc), TROPICULTURA, 2011, 29, 3, 161-167. (2011).

[15] C. T. Thanh Huong, N. T. H. Duong, N. T. T. Hien. Contamination of some bacteria isolated from chicken meat in retail markets in Hanoi and examination of the antibiotic resistance ability of Salmonella and E. coli strains isolated, J. Sci. Dev. 2009, 7 (Eng.Iss. 2): 181 - 186. (2009).

[16] E. A Abdellah, R. F. Fouzia, O. Bouchra. Prevalence and Antibiogram Study of Escherichia coli and Staphylococcus aureus in Turkey Meat in Morocco. Pharmaceut Anal Acta 4: 270. doi: 10.4172/21532435.1000270. (2013).

[17] C. Zhao, B. GE, J. D. Villena, R. Sulder, E. yeh, S. Zhao, D. G. White, D. Wagner, J. Meng. Prevalence of Campylobacter spp., Escherichia coli, and Salmonella serovars in retail chicken, turkey, pork and beef from Greater Washington, D.C, Area. Approximately Appl Microbiol, 67:5431-5436. (2001).

[18] N. Gupta, S. Gupta. Microbial Quality of chicken meat samples collected from Durg (C. G.). Journal of veterinary public health, 7: 79-81.43 (2009).

[19] I. R. Iroha, E. C. Ugbo, D. C. Ilang, A. E. Oji, T. E. Ayogu. Bacteria Contamination of raw meat sold in Abakaliki, Ebonyi State Nigeria. J. Pub. Health. Epidemiol., 3: 49-5317, (2011). 
[20] P. Feng Escherichia coli. In : Labbé R.G., García S. (Eds.), Guide to foodborne pathogens. John Wiley and Sons : New York, 2001, 143-162. (2001).

[21] Cartier. P. (1990). Méthodologie de contrôle de la qualité hygiénique d'un avant de bovins. Viandes et Produits Carnés 11 : 215-216. (2001).

[22] A. Boudouika et K. GHIAT. Étude de la contamination bactérienne des viandes réfrigérées par les Pseudomonas de la flore psychrotrophe. Mémoire Master: république algérienne démocratique et populaire, ministère de l'enseignement supérieur et de la recherche scientifique, université des frères Mentouri Constantine faculté des sciences de la nature et de la vie. (2017).

[23] M. L. Hutchison, L. D. Walters, G. C. Mead, M. Howell, V. M. Allen. An assessment of sampling methods and microbiological hygiene indicators for process verification in poultry slaughterhouses. Journal of Food Protection 69:145-153. (2006).

[24] Y. Ghafir, B. China, K. Dierick, L. De Zutter, Daube G. Hygiene Indicator Microorganisms for Selected Pathogens on Beef, Pork, and Poultry Meats in Belgium, Journal of Food Protection, Vol. 71, No. 1, 2008, Pages 35-45. (2008).

[25] C. O. Gill, C. Landers. Effects of spray-cooling processes on the microbiological conditions of de contaminated beef carcasses. Journal of Food Protection 66:1247-1252. (2003).

[26] C. F. A. Salifou, K. C. Boko, Y. E. Attakpa, R. Agossa, I. Ogbankota, S. Farougou, G. A Mensah, S. Salifou, A. Clinquart, A. K. I. Youssao. Evaluation de la qualité bactériologique de viande fraîche de bovins abattus aux abattoirs de CotonouPorto-Novo au cours de la chaîne de distribution Journal of Animal \&Plant Sciences, 2013. Vol.17, Issue 2: 2567-2579. (2013).

[27] J.Pierre, Hygiène et propreté des surfaces en milieu agro-alimentaire : produits humides. Collection Guide pratiques. p 25. (1998).

[28] F. Van Immerseel, J. De Buck, F. Pasmans, G. Huyghebaert, F. Haesebrouck, R. Ducatelle. Clostridium perfringens in poultry: An emerging threat for animal and public health. Avian Pathology 33:537-549. (2004).

[29] M. Lindblad, H. Lindmark, S. T. Lambertz, R. Lindqvist. Microbiological baseline study of broiler chickens at Swedish slaughterhouses. Journal of Food Protection 69:2875-2882. (2006).

[30] Q. Wen, B. A. McClane. Detection of enterotoxigenic Clostridium perfringens type A isolates in American retail foods. Appl. Environ. Microbiol. 70:2685-2691. (2004).

[31] M. Alvarez-Astroga, R. Capita, C. Alonse-Calleja, B. Moreno, M. del Camino Garcia Fernandez. Microbiological quality of retail chicken by products in Spain. Meat science 62:45-50. (2002.).
[32] J.K. Skeels. Staphylococcies. In Clanek (ed.). 10th edition Diseases of poultry. Mosby-wolf, London, UK (1997).

[33] B. Simonsen. Microbiological criteria for poultry products. PP: 221-249. In Mead G.C. (ed.), Processing of poultry. Elsevier Applied Science. (1989).

[34] R. Gorman, S. Bloomfield, C. C. Adley. A study of cross contamination of food borne pathogens in the domestic kitchen in the republic of Ireland. Int. J. of Food Microbiol. 76:143-150. (2002).

[35] L. Q. Huong, R. Fries, P. Padungtod, T. T. Hanh, N. Kyule Moses, P. O. Baumann Maximilian, H. Zessin Karl. Prevalence of Salmonella in retail chicken meat in Hanoi, Vietnam. Annals of the New York Academy of Sciences, 1081, 257-261. (2006).

[36] T. T. Phan, L. T. Khai, N. Ogasawara, N. T. Tam, A. T. Okatani, M. Akiba, H. Hayashidani. Contamination of Salmonella in retail meats and shrimps in the Mekong delta, Vietnam. J. Food Prot. 68:1077-1080. (2005).

[37] J. E. L. Corry, V. M. Allen, W. R. Hudson, M. F. Breslin, R. H. Davies. Sources of Salmonella on broiler carcasses during transportation and processing: Modes of contamination and methods of control. Journal of Applied Microbiology 92:424-432. (2002).

[38] G. Rasschaert, K. Houf, C. Godard, C. Wildemauwe, M. Pastuszczak-Frak, L. De Zutter. Contamination of carcasses with Salmonella during poultry slaughter. Journal of Food Protection 71:146-152. 6. (2008). 